\title{
Masalah underachiever pada anak berbakat di sekolah
}

\author{
Haryati Dahlia ${ }^{1 *}$, Widia Elvia Roza ${ }^{2}$ \\ Universitas Negeri Padang \\ *) Correspondence author; email: haryatidahlia@gmail.com
}

\begin{abstract}
Saat ini masih banyak anak berbakat yang kurang mendapatkan perhatian dari lingkungan sekolah. Hal ini dikarenakan ketidaktahuan guru akan keberbakatan anak dan penanganan yang diberikan kepada anak berbakat, sehingga anak berbakat menjadi tidak tersalurkan keberbakatannya yang menjadikan anak underachiever.
\end{abstract}

Keywords: underachiever, anak berbakat

Article History: Received on 14/10/2017; Revised on 15/11/2017; Accepted on 16/11/2017; Published Online: $22 / 12 / 2017$

This is an open access article distributed under the Creative Commons Attribution License, which permits unrestricted use,
distribution, and reproduction in any medium, provided the original work is properly cited. (C)2017 by author.

\section{INTRODUCTION}

Keberbakatan hingga kini masih menjadi wacana yang sangat menarik, baik bagi yang terlibat langsung dengan persoalan keberbakatan maupun yang tidak. Bahkan menjadi lebih menarik lagi, karena banyak terjadi miskonsepsi terhadap keberbakatan. Secara umum. Keberbakatan dapat diartikan sebagai kemampuan unggul yang memungkinkan seseorang berinteraksi dengan lingkungan dengan tingkat prestasi dan kreativitas yang sangat tinggi (Wahab, 2016).

Sering kita jumpai banyak pernyataan, seperti: “Dia adalah seorang seniman sejak lahir, dia adalah seorang ilmuwan yang dibesarkan oleh lingkungan pendidikan yang kondusif, dia adalah olahragawan terkenal yang dibesarkan dari lingkungannya, sebagainya. Yang jelas bahwa keberhasilan pada dasarnya tidak pernah datang kepada kita dengan mudah; Kita harus belajar dengan keras dan sungguh-sungguh. Semuanya menggambarkan bahwa keberbakatan itu pada hakekatnya memiliki beberapa faktor bawaan plus motivasi dan stamina untuk belajar kehidupan (Wahab, 2016).

Bakat adalah kemampuan yang merupakan sesuatu yang inherent $\|$ dalam diri seseorang, dibawa sejak lahir dan terkait erat(Pangestuti, 2017)

Dengan struktur otak.Bakat merupakan suatu mencapai prestasi belajar memiliki dalam arti berpotensi untuk mencapai prestasi belajar sampai ke tingkat tertentu. Bakat siswa dapat dipengaruhi 2 faktor yaitu: faktor Internal (minat, motivasi, keberanian atau beresiko, keuletan dalam menghadapi tantangan, dan egigihan dalam mengatasi kesulitan yang timbul). Sedangkan faktor eksternal (kesempatan maksimal untuk mengembangkan diri, sarana dan prasarana, ukungan dan dorongan orang tua dan keluarga, dan lingkungan tempat tinggal) (Fadillah, 2016). 
Identifikasi bakat anak merupakan hal yang sangat penting dilakukan. Hal ini dikarenakan setiap anak memerlukan program pendidikan yang sesuai dengan bakat mereka masing-masing sehingga dapat mengembangkan dan menggunakan bakat mereka secara maksimal. Lucy menyatakan bahwa disekolah ditemukan kurang lebih $40 \%$ anak berbakat yang tidak mampu berprestasi sesuai dengan kemampuan mereka sehingga tergolong sebagai anak kurang berprestasi. (Salisah et al., 2015).

Setiap anak terlahir dengan potensi yang unik dan beragam, masing-masing dari mereka memiliki bakat dan minat yang berbeda antara

yang satu dengan yang lainnya. Seiring berjalannya waktu, potensi-potensi yang dimiliki seorang anak teridentifikasi melalui berbagai pengalaman belajarnya, beragam faktor mempengaruhi bagaimana seorang anak dapat memaksimalkan potensi yang dimilikinya. Anak yang kurang mampu memahami dan menggali potensi yang dimilikinya, serta kegagalan lingkungan memahami berbagai potensi anak menimbulkan suatu situasi yang menyebabkan anak mengalami permasalahan dalam proses belajarnya sehingga muncul istilah anak underachievement (Dewi \& Trisnawati, 2017)

Anak-anak yang termasuk dalam kualifikasi berbakat perlu mendapat-perhatian khusus (UUSPN Tahun 1989), kini disebutkan berhak mendapat layanan pendidikan khusus, sebagaimana dinyatakan dalam UU No. 20 Tahun 2003 Pasal (5) ayat (4) bahwa: Warga negara yang memiliki potensi kecerdasan dan bakat istimewa berhak memperoleh pendidikan khusus. Selanjutnya dalam Pasal (12) ayat (1) poin (b) dan (f) dinyatakan bahwa: Setiap peserta didik pada setiap satuan pendidikan berhak : mendapatkan layanan pendidikan sesuai bakat, minat, dan kemampuannya; serta menyelesaikan program pendidikan sesuai dengan kecepatan belajar masing-masing dan tidak menyimpang dari ketentuan batas waktu yang ditetapkan (dalam undang-undang ini digunakan istilah anak dengan potensi kecerdasan dan bakat istimewa yaitu anak berbakat).(Sunardi (UPI), 2008).

\section{DISCUSSION}

\section{Bakat}

Bakat adalah kemampuan alamiah untuk memperoleh pengetahuan atau keterampilan yang bisa bersifat umum atau khusus. Perbedaan bakat anak bisa dilihat dari berbagai aspek, seperti IQ, bakat, minat, kemampuan, kepribadian, kondisi fisik, pengalaman, perkembangan dan interaksi social. Bakat adalah kemampuan alamiah untuk memperoleh pengetahuan dan terampilan, baik yang bersifat umum dan khusus. Bakat seseorang berkemungkinan untuk mencapai prestasi dalam bidang tertentu (Fadillah, 2016). anak berbakat adalah anak yang mampu mengembangkan interaksi antara kemampuan di atas rata-rata, task commitment yang tinggi dan highly creativity (Koswara, 2009).

Ada enam bakat menurut US Office Of Education (USOE) America, yaitu: (1) intelektual umum; (2) akademik khusus; (3) berfikir kreatif-produktif; (4) kemampuan memimpin; (5) bidang seni dan pertunjukkan; (6) kemampuan psikomotor. 
Krik \& Gallagher (dalam, Abdurrachman, 1995) pada awalnya, keberbakatan memiliki pengertian yang berbeda-beda untuk tiap latar budaya. Dalam kebudayaan Yunani kuno yang dimaksud dengan anak berbakat adalah anak yang memiliki kecakapan luar biasa dalam berpidato, sedangkan di Roma ialah insinyur atau prajurit. Pengertian berbakat di Amerika Serikat pada mulanya di kaitkan dengan skor tes intelegensi Standford Binet yang dikembangkan oleh Terman setelah perang dunia II. Anak- anak yang memiliki skor IQ 125 atau lebih dinyatakan sebagai anak berbakat. (Konseling \& Siswa, 2016).

Anak berbakat akan menjadi sumber daya yang produktif dalam pembangunan jika potensi mereka dibina secara optimal. Perhatian berbagai pihak kepada anak berbakat sekarang ini memang belum begitu besar. mungkin berdasarkan kenyataan bahwa tanpa bimbingan khusus pun mereka akan dapat berkemtang. pendapat ini tidak selamanya benar (Sidqyah, 2014).

Karakteristik anak berbakat,di antaranya sebagai berikut: 1) Menunjukkan kemampuan di atas rata-rata; 2) Menunjukkan Komitmen yang terhadap tugas; 3) Menunjukkan kreativitas yang tinggi (Wahab, 2016).

\section{Underachiever}

Istilah underachiever mengacu pada siswa yang memiliki taraf intelegensi yang tinggi akan tetapi prestasi belajarnya rendah (di bawah rata-rata) (Pratama, 2017). Yang dimaksud dengan Underachiever adalah anak yang mengalami hambatan dalam perkembangannya. Bila dilihat dalam hal potensi intelektual mereka, kondisi potensi intelektual mereka termasuk dalam kategori cukup, baik, bahkan sangat baik. Namun, underachiever memiliki performa pada level dibawah yang diharapkan atau yang diprediksikan. Anak yang underachiever mungkin merupakan anak yang kreatif, verbal yang baik, kemampuan matematis yang tinggi, namun mereka tidak sukses di sekolah. Dengan demikian dapat dikatakan bahwa kategori underachiever diberikan kepada anak yang belum dapat mengenali dan menggunakan potensinya secara penuh untuk mencapai performa yang seharusnya dan diharapkan (Francis, n.d.).

Menurut Prayitno dan Erman Amti (Lelono \& Padang, 2011) underachiever identik dengan keterlambatan akademik yang berarti bahwa "keadaan siswa yang diperkirakan memiliki intelegensi yang cukup tinggi, tetapi tidak dapat memanfaatkannya secara optimal". Siswa yang tidak memiliki motivasi dalam belajar sering menjadi penghambat anak dalam belajar. Artinya jika di dalam diri siswa kurang memiliki motivasi berprestasi bisa jadi ia akan menjadi anak underachiever.

Underachiever adalah suatu kondisi dimana seorang anak menunjukkan prestasi yang berada di bawah kemampuan anak sesungguhnya. Hal ini bisanya terjadi pada anak-anak yang memiliki tingkat intelegensi yang tinggi namun prestasinya di sekolah berada di bawah performance anak tersebut. Anak gifted dan disleksia adalah anak-anak yang cukup sering menjadi anak yang underachiever. Pada banyak kasus anak disleksia di sekolah menunjukkan prestasi belajar yang buruk, padahal dari segi tingkat kemampuan intelegensia, mereka berada di angka rata-rata dan bahkan banyak yang di atas rata-rata. Pada anak gifted, kejadian anak mengalami underachiever adalah bisanya diakibatkan karena tinggkat intelegensia mereka yang sangat tinggi, akhirnya minat mereka jadi lebih terbatas, sehingga seringkali muncul perilaku mengabaikan materi- 
materi yang tidak diminati, yang kemudian berdampak pada hasil tidak bagus pada materi yang tidak diminati. Hal ini terjadi bukan karena tidak mampu, melainkan karena tidak menyukai dan pada akhirnya malas untuk mempelajarinya (Rahmawati, 2013). Anak yang underachiever mungkin merupakan anak yang kreatif, verbal yang baik, kemampuan matematis yang tinggi, namun mereka tidak sukses di sekolah. Dengan demikian dapat dikatakan bahwa kategori underachiever diberikan kepada anak yang belum dapat mengenali dan menggunakan potensinya secara penuh untuk mencapai performa yang seharusnya dan diharapkan (Francis, n.d.).

Underachievement atau prestasi belajar di bawah kemampuan terjadi pada siswa apabila terdapat ketidaksesuaian antara prestasi sekolah yang di-capai siswa dengan indeks kemampuannya sebagaimana nyata dari tes inteli-gensi, tes bakat, kreativitas, atau dari data observasi, sehingga tingkat prestasi sekolah yang dicapai lebih rendah dibandingkan dengan kemampuan anak (Sunawan \& Semarang, 2016).

Underachievement adalah suatu kondisi di mana seseorang tidak mampu atau tidak dapat berprestasi sesuai dengan bakat dan potensi yang dimilikinya, atau dapat pula diartikan sebagai prestasi rendah dibandingkan dengan tingkat kecerdasan yang dimiliki (Anak \& Wulan, 2014)

\section{Masalah yang dialami underachiever}

Masalah pribadi yang dialami peserta didik underachiever sebagai berikut : (a) Menemukan secara berulang-ulang konsep diri yang negatif, (b) Merasa tidak diterima keluarga, (c) Tidak bertanggung jawab terhadap perilakunya dan tidak dapat keluar dari konflik, (d) Menantang pengaruh yang diberikan oleh oranglain, (e) Merasa jadi korban, (f) Tidak menyukai sekolah dan guru serta memiliki sikap negatif terhadap sekolah, (g) Memiliki motivasi dan keterampilan akademik yang lemah atau kurang, (h) Kurang dalam penyelesaian intelektual, (i) Berpegang teguh pada status kepemimpinan yang rendah, (j) Tidak memiliki hobi, minat dan kreativitas yang dapat digunakan dalam mengisi waktu luang dan (k) Tidak mampu berpikir dan merencanakan masa depan (Aprilnayendi, 2015). Masalah yang dihadapi dalam pelayanan anak berbakat antara lain: tidak fokus pada kebutuhan anak, pemahaman guru terhadap anak berbakat yang belum menyeluruh, dan proses identifikasi yang belum tepat (Kebudayaan, 2012).

\section{CONCLUSIONS}

Anak berbakat three-conceptions of giftedness yang dikemukakan biasanya secara sosial tampak matang, karakteristik keberbakatan sisi internal mereka cenderung menginternalisir mencakup tiga hal, yaitu kemampuan di atas rata masalah yang dihadapi, merasa kesepian dan rata, komitmen pada tugas, dan kreativitas. Terisolasi, menilai diri terhambat dalam relasi. Diantara tiga dengan teman sebaya, merasa kurang diterima karakteristik tersebut, tidak ada karakteristik orang lain, dan mengalami kesulitan dalam tunggal yang menciptakan keberbakatan, ketrampilan sosial. 


\section{REFERENCES}

Anak, U. P., \& Wulan, L. R. (2014). Underachievement Pada Anak .... (Lia Ratna Wulan) 1.

Aprilnayendi, M. (2015). Underachiever dan implikasinya dalam pelayanan BK ( Studi Deskriptif Pada Kelas X di SMA Adabiah 2 Padang ) JURNAL Diajukan Sebagai Salah Satu Syarat untuk Memperoleh Gelar Sarjana Pendidikan ( STRATA 1 )

Berpikir, K., \& Siswa, K. (2015). Metodik Didaktik Vol. 10, No. 1, Juli 2015 PENERAPAN PENDEKATAN, 10(1), 69-77.

Dewi, R. S., \& Trisnawati, M. (2017). Identifikasi Anak Underachievement (Underachiever dan Gifted Underachiever). Jurnal Pendidikan, 1(2), 1-9.

Fadillah, A. (2016). Belajar Matematika Siswa. Jurnal Matematika Dan Pendidikan Matematika, 1(2), 113-122.

Francis, N. P. (n.d.). Bagi mahasiswa underachiever, 1(45), 596-601.

Hamimah, F. N., Konseling, B., Pendidikan, F. I., \& Surabaya, U. N. (2014). Motivasi belajar siswa underachiever di sekolah dasar development of guidebook for parents to giving learning motivation for the underachiever student' $\mathrm{s}$ in elementary school, 1-8.

Kebudayaan, K. P. dan. (2012). Konvensi Nasional Pendidikan Indonesia VII 2012, 7, 17-19.

Konseling, B., \& Siswa, B. (2016). Bimbingan Konseling Bagi Siswa Cerdas dan Berbakat, 1(1), 3036.

Koswara, H. (2009). Di Kota Bandung, 1, 43-56.

Lelono, S., \& Padang, U. N. (2011). Masalah siswa underachiever dan peran guru bimbingan dan konseling, 5(1), 77-89.

Pangestuti, R. W. (2017). Strategi layanan perencanaan individual, 159-172.

Pratama, B. D. (2017). Layanan bimbingan dan konseling dalam mengatasi siswa underachiever. Junal Ilmiah Cunsellia, 7(1), 1-10.

Pratama, B. D., \& Kadafi, A. (2018). Peran Konselor dalam identifikasi masalah dan kebutuhan siswa underachiever, 2(1), 452-456.

Rahmawati, R. (2013). Bimbingan dan Konseling Untuk Anak Underachiever. Jurnal Paradigma, $8(15), 1-24$.

Salisah, F. N., Lidya, L., Defit, S., Informasi, J. S., Sains, F., \& Suska, U. I. N. (2015). Sistem Pakar Penentuan Bakat Anak Dengan Menggunakan Metode Forward Chaining. Jurnal Rekayasa Dan Manajemen Sistem Informasi, 1(1), 62-66.

Sidqyah, H. (2014). Klasifikasi Anak Berkebutuhan Khusus.

Sunardi (UPI). (2008). Karakteristik dan kebutuhan anak berbakat dan implikasi dalam layanan bimbingan da konseling karir. Plb Fip Upi, 1-17.

Sunawan, S., \& Semarang, U. N. (2016). Beberapa Bentuk Perilaku Underachievement dari Perspektif Teori Self Regulated Learning, (September), 1-15. https://doi.org/10.17977/jip.v12i2.73

Wahab, R. (2016). Mengenal anak berbakat akademik dan upaya mengidentifikasinya, 1-11. Retrieved from http://staff.uny.ac.id/sites/default/files/lain-lain/rochmat-wahab-mpd-ma-drprof/mengenal-anak-berbakat-akademik-dan-mengidentifikasikannya.pdf

Wandansari, Y. (2011). Faktor Protektif pada Penyesuaian Sosial Anak Berbakat. Insan, 13(02), 8595. 